\title{
LA CLÁUSULA SUARECIANA SOBRE LA ESCLAVITUD DE LOS NEGROS*
}

\author{
LUIS-CARLOS AMEZÚA AMEZÚA \\ Universidad de Valladolid
}

\begin{abstract}
RESUMEN: Los teólogos y juristas españoles de la primera modernidad criticaron duramente las condiciones de la trata de esclavos africanos. Fueron pioneros en rechazar las condiciones de venta, aunque todavía admitieron la institución de la esclavitud. También Francisco Suárez opinó al respecto, limitando la esclavitud de los negros por razones del bien común y compensando con un salario justo por sus trabajos en las minas. Hasta ahora se desconocía esta opinión de Suárez porque no hay escritos directos sino referencias de autores coetáneos. En este artículo seleccionamos argumentos de teólogos y juristas del siglo XVI y exponemos la solución de Suárez, rastreando las atribuciones. EI probabilismo facilita conciliar la libertad de conciencia con la estabilidad de las instituciones sociales, en concreto con la institución de la esclavitud.
\end{abstract}

PALABRAS CLAVE: esclavitud; esclavos negros; Francisco Suárez; tráfico de esclavos; probabilismo.

\section{The Suarezian Proviso to African Slavery}

ABSTRACT: The Spanish theologians and jurist in early modern times harshly criticized the conditions of the African slave trade. They were inclined to reject the conditions of sale, although they still admitted the institution of slavery. Francisco Suárez also opined in this regard, limiting the slavery of blacks for reasons of the common good and compensating with a fair wage for their work in the mines. Until now, this opinion of Suárez was unknown because there are no direct writings but references of contemporaneous authors. In this article we will select arguments of $16^{\text {th }}$ century theologians and jurists and expose Suárez's solution, tracing the attributions. Probabilism facilitates reconciliation of freedom of conscience with the stability of social institutions, in particular with the institution of slavery. KEY WORDS: slavery; black slaves; Francisco Suárez; African slave trade; probabilism.

\section{INTRODUCCIÓN}

En esta investigación vamos a presentar, en primer lugar, una selección de los teólogos y juristas españoles pioneros en cuestionar las condiciones de la trata de esclavos, que reprochan las condiciones de ejercicio y advierten contra la comisión de tropelías en origen al adquirir esclavos. Ninguno se opuso, todavía, a la institución oprobiosa, lo cual no puede extrañar porque el abolicionismo militante apenas culminó en el siglo XIX y porque los ramalazos

Este trabajo se ha actualizado en el marco del Proyecto I+D+i del MINECO/FEDER "Pensamiento y tradición jesuita y su influencia en la Modernidad desde las perspectivas de la Historia, la Traductología y la Filosofía Jurídica, Moral y Política»(FFI2015-64451-R), dirigido por Juan Antonio Senent de Frutos. Responde a una trayectoria dilatada desde proyectos anteriores del GIR Teorías jurídicas y políticas de la modernidad, continuada con los resultados del capítulo tercero de mi tesis doctoral y otros materiales consultados durante la estancia de investigación en la Universidad de Coimbra apoyada con el Plan de Movilidad UVA 2014. 
de subversión (como el de Moirans o de algún otro pensador aisladamente) fueron silenciados para evitar la generalización pública de los reparos contra la existencia de la esclavitud y el maltrato de las personas esclavizadas, fueran de cualquier color, en beneficio del sistema socio-económico.

Contextualizado de esa manera el debate doctrinal, después exponemos la novedad de la opinión de Francisco Suárez, en realidad un descarte del autor sobre la cuestión, que ha de completarse con la postura que le atribuyen otros coetáneos. El jesuita Fernando Rebelo es la fuente original de información y a su través llegó a los demás la supuesta opinión de Suárez. Se supone que Suárez admitió la esclavitud de los negros con una restricción que he denominado como la "cláusula suareciana» desde el título de este artículo. Esa restricción se atiene al fin del bien común universal consistente en la obtención de metales de oro y plata, para cuya extracción era imprescindible la mano de obra esclava de origen africano; y siempre que se compense a los negros por esos trabajos peligrosos.

A continuación, concluimos con la solución a las dudas sobre la adquisición del esclavo y la validez de las segundas ventas. Para ello propongo una interpretación extensiva de la doctrina probabilista, perfectamente razonable porque también Martín de Azpilcueta había aplicado el derecho canónico para resolver la duda acerca de la adquisición de una persona como esclava. El adquirente de buena fe podía conservar la propiedad del esclavo sin que sus dudas hiciesen aflorar la obligación de liberarlo e indemnizarlo. La buena fe consiste en el conocimiento de la legitimidad del título original, pero cuando surgen dudas sobre la veracidad del mismo y hay serias sospechas de la injusticia cometida contra una persona libre que ha sido esclavizada sin causa, en este caso operan las presunciones jurídico-morales del poseedor de buena fe. Del mismo modo que Azpilcueta aplicó esa doctrina, la extendemos a Suárez con la cautela imprescindible, porque el probabilismo del Eximio admitiría, tal vez, soluciones diferentes en cada caso concreto, ya que las controversias prácticas tienen que adecuarse hic et nunc a las circunstancias.

Sostengo que la solución que mejor se acomoda al modo suareciano tiene que equilibrar la libertad individual y la tranquilidad de la conciencia con el aseguramiento del orden institucional que hace viable aquellas libertades.

\section{TeÓlogos y JURISTAS ESPAÑOLES CONTRA LA TRATA}

Los teólogos y juristas hispanos negaron la servidumbre natural y rechazaron que existiera algún grupo de seres humanos destinados por su propia naturaleza al servicio de otros hombres superiores. Los miembros de la Escuela de Salamanca o influidos de alguna manera por ella, desde Vitoria hasta Suárez, afirmaron que los habitantes del Nuevo Mundo recién descubierto eran también seres humanos, a los que debía respetárseles el dominio que tenían sobre sus personas y sus bienes. 
Muy otra parece ser la condición que se atribuye a los negros africanos, pues a diferencia de los indios no hay simultáneamente una defensa jurídica ni teológica coherente y decidida ${ }^{1}$.

Los negros podían ser esclavizados porque eran más aptos para realizar trabajos duros que los aborígenes americanos y porque desde la perspectiva del ius commune tenían un estatus legal inferior. No influyeron consideraciones sobre el color, como si en el fondo fueran un eslabón intermedio entre los brutos y los humanos o una raza maldecida descendiente de camitas. Lo cierto es que se trataba de una simple cuestión legal, como ha resumido con sencillez Anthony Pagden ${ }^{2}$. Los habitantes de esas regiones africanas no eran súbditos del rey portugués ni estaban bajo la jurisdicción política de ningún monarca europeo, por lo cual el compromiso de estos era mucho más difuso que el compromiso de los reyes castellanos con sus vasallos en las Indias.

1 Está muy bien escrito y aporta una información útil sobre los argumentos utilizados en la época para justificar la esclavitud negra y sobre la realidad vivida en Hispanoamérica, aunque abarca varios siglos, el libro de ANDRÉs-GALLEGo, J., La esclavitud en la América española, Madrid, Encuentro, 2005. Hace una agrupación de autores coetáneos y argumentos sobre la licitud de la esclavitud negra, con referencia a fuentes directas, García AÑoveros, J. M., El pensamiento y los argumentos sobre la esclavitud en Europa en el siglo XVI y su aplicación a los indios americanos y a los negros africanos, Madrid, CSIC, 2000, pp. 159-174 (que corresponden a la Parte XI: «De la esclavitud de los negros»). Para una aproximación rápida son muy útiles: Domínguez Ortiz, A., "La esclavitud en Castilla durante la Edad Moderna», en Íd., La esclavitud en Castilla en la Edad Moderna y otros estudios de marginados, Granada, Comares, 2003, pp. 1-64; Piqueras, J. A., La esclavitud en las Españas. Un lazo transatlántico, Barcelona, La Catarata, 2012; Mannix, D. P. y Cowley, M., Historia de la trata de negros, trad. Eduardo Bolívar Rodríguez y revisado por P. Azcárate Diz, Madrid, Alianza, 1970, cap. 1 y 2, pp. 15 57; SAco, J. A., Historia de la esclavitud, [1837-1879-1881], Sevilla, Espuela de Plata, 2009, la segunda parte, pp. 251-443 (edita una selección de la extensa obra de este intelectual cubano, sin las notas); Phillips, W. D., Historia de la esclavitud en España, Madrid, Editorial Playor, 1990. Por supuesto, hay una amplia literatura sobre la esclavitud y la trata afro-americana: Navarro Azcue, C., La abolición de la esclavitud negra en la legislación española, 1870-1886, Madrid, Cultura Hispánica, 1987; Lucena Salmoral, M., Regulación de la esclavitud negra en las colonias de la América española (1503-1886): documentos para su estudio, Alcalá, Instituto de Estudios Latinoamericanos, 2005; Mellafe, R., La esclavitud en Hispanoamérica, Buenos Aires, Eudeba, 1987; VILa VILAR, E., Hispanoamérica y el comercio de esclavos, $2^{\mathrm{a}}$ edición, Sevilla, Universidad de Sevilla, 2015; Morgan, K., Cuatro siglos de esclavitud trasatlántica, Barcelona, Crítica, 2017; MARTÍN CASARES, A. (coord.), Esclavitud, mestizaje y abolicionismo en los mundos hispánicos, Granada, Universidad de Granada, 2015; PHILlips, W. D., La esclavitud desde la época romana hasta los inicios del comercio transatlántico, Madrid, Siglo XXI, 1989; Thомаs, H., La trata de esclavos. Historia del tráfico de seres humanos de 1440 a 1870, trad. Victoria Alba y C. Boune, Barcelona, Planeta, 1998; KLeIn, H. S. y Vinson, B., African slavery in Latin America and the Caribbean, $2^{\mathrm{a}}$ ed., New York, Oxford UP, 2007.

2 Pagden, A., La caída del hombre natural. El indio americano y los orígenes de la etnología comparativa, trad. Belén Urrutia Domínguez, Madrid, Alianza, 1988, p. 58. Los elementos racistas fueron insignificantes, según RuBiés, J. P., «Were early modern Europeans racist?», en Morris-Reich, A. y Rupnow, D. (eds.), Ideas of "Race» in the History of Humanities, Cham, Palgrave Macmillan, 2017, pp. 33-87; más severo, SwEET, J. H., «The Iberian Root of American Racist Thought», The William and Mary Quarterly, vol. 54, N. 1 (1997), pp. 143-166. 
Oposición estricta a la esclavitud de los negros no hubo. Sin embargo, encontramos una resistencia clara a reconocer pasivamente las prácticas esclavistas en valiosos escritos académicos de los dominicos Domingo de Soto y Tomás de Mercado, en Bartolomé de Albornoz así como en los jesuitas Luis de Molina y Diego de Avendaño. Y los primeros abolicionistas militantes, allá por 1682, fueron los capuchinos Francisco José de Jaca y Epifanio de Moirans ${ }^{3}$. También merecen elogio Alonso de Sandoval y su discípulo Pedro Claver, el «apóstol de los negros» (canonizado en 1888), jesuitas que desempeñaron principalmente en Cartagena de Indias su misión evangelizadora entre los negros, adoctrinando a más de trescientos mil ${ }^{4}$.

El mismo Bartolomé de Las Casas (1484-1566), que defendió con ardor a los indios, encontró una solución cómoda para mantener las necesidades productivas en las minas y plantaciones, sustituyendo la mano de obra nativa por la importación de esclavos africanos. Ahora bien, el gran «defensor de los indios» aplicará más adelante los mismos argumentos en defensa de los guanches y los negros, criticando el cruel comportamiento de los portugueses con los pobladores de la costa guineana y Cabo Verde 5 .

Rechazó que fueran reales las únicas tres causas posibles para hacer la guerra justa contra los infieles de cualquier categoría ${ }^{6}$. Ninguna de ellas

3 Vid. López García, J. T., Dos defensores de los esclavos negros en el siglo XVII: Francisco José de Jaca y Epifanio de Moirans, Caracas, Universidad Católica Andrés Bello, 1982; Pena González, M. A., Francisco José de Jaca: la primera propuesta abolicionista de la esclavitud en el pensamiento hispano, Salamanca, Universidad Pontificia, 2003. En especial, JACA, F. J. de, Resolución sobre la libertad de los negros y sus originarios, en estado de paganos y después ya cristianos. La primera condena de la esclavitud en el pensamiento hispano, edición crítica por M. A. Pena González, (CHP $2^{a}$ Serie, vol. 11) Madrid, CSIC, 2002: contiene el estudio preliminar (pp. XXIII-XCVIII), la Resolución de 1682 (pp. 1-70) y el resto de las 370 páginas son documentos del Consejo de Indias y otros biográficos.

4 Restrepo, E., «De Instauranda cethiopum salute: Sobre las ediciones y características de la obra de Alonso de Sandoval», Tabula Rasa. Bogotá, No 3 (2005), pp. 13-26. La obra de Sandoval es imprescindible todavía hoy para los estudios de etnografía afro-americana. De ella contamos con una edición moderna, hoy descatalogada, con el desafortunado título Un tratado sobre la esclavitud (introducción y transcripción de Enriqueta Vila Vilar, Madrid, Alianza, 1987), pues el título original, que le dio su autor desde la segunda edición aumentada de 1647, describe perfectamente el contenido: tratado de cómo se ha de restaurar la salvación de los negros. Respecto de la misión evangelizadora de los jesuitas hay también enfoques actuales más críticos: GrEEN, R. L., «Africans in spanish catholic thought, 1568-1647», Black Theology, 11 (2013), pp. 96-116.

Las Casas, B., Historia de las Indias, lib. 1, cap. 17-27. Estos capítulos deben considerarse junto a las más conocidas referencias del lib. 3, cap. 102 y 129; los primeros vendrían a constituir una especie de pequeña historia sobre el África occidental. El P. Las Casas empezó a escribir esta obra en 1527, aunque no fue publicada hasta 1875. Lo que se difundió de inmediato, ya desde su publicación en 1542, fue el resumen de la monumental Historia, publicado como la Brevísima relación de la destruición de las Indias, que contribuyó enormemente a la leyenda negra antiespañola.

6 El opúsculo africano de fray Bartolomé de Las CASAS contenido en Historia de las Indias, lib. 1, cap. 17-27, ha sido editado exento por el padre dominico Isacio Pérez Fernández, con el título de Brevísima relación de la destrucción de África, Salamanca, San Esteban, 1989. 
confluía en las violencias practicadas en la costa africana, pues la población guanche y africana no había atacado a los cristianos, ni impedía predicar la religión cristiana, ni tampoco habían invadido territorios u ocupado bienes de los cristianos ${ }^{7}$.

Las Casas rectificó su postura inicial sobre los negros, a partir de 1552, en el libro III de la Historia de Indias, oponiéndose a la venta perpetua de las encomiendas en el Perú:

«Este aviso de que se diese licencia para traer esclavos negros a estas tierras dio primero el clérigo Casas, no advirtiendo la injusticia con que los portugueses los toman y hacen esclavos; el cual, después de que cayó en ello, no lo diera por cuanto había en el mundo, porque siempre los tuvo por injusta y tiránicamente hechos esclavos, porque la misma razón es dellos que de los indios» ${ }^{8}$.

También Domingo de Soto (1495-1560) fue de los primeros en incorporar en sus lecciones académicas alusiones al problema con los negros y nos proporciona una buena muestra del reconocimiento de la validez de esas transacciones a pesar de las sospechas sobre los vicios del consentimiento. En su Relección de dominio, impartida en las aulas salmantinas entre marzo y junio de 1535, admitía la compra de esclavos cuando una persona se vendiera a otra forzada por la necesidad, lo cual suponía que "así está hoy en uso entre estos etíopes que se entregan a los portugueses forzados por el hambre aguda y la inanición»9.

El maestro dominico cambiará su actitud posteriormente en la primera edición en 1553-1554 de su magno tratado De iustitia et iure, donde precisa más sobre la admisión de la esclavitud cuando los negros se vendieran voluntariamente. Pero, advertía Soto, de ser ciertas las noticias que corrían sobre los engaños y violencias cometidos contra ellos, entonces tanto los captores como sus actuales poseedores tenían la obligación de manumitirlos, aunque perdieran el precio pagado en la compraventa ${ }^{10}$.

Igualmente Tomás de Mercado (1523-1575) repudia la práctica habitual de los portugueses, pero, al final, solamente recomendaba a las conciencias escrupulosas no comprar esclavos. En la Suma de tratos y contratos, cuya primera edición salió en 1569, dedica el capítulo 20 del segundo libro, a describir con minuciosidad las prácticas de captura, las modalidades de transporte y las crueldades con los africanos, bajo el título «Del trato de los

7 Las Casas, B., Brevísima relación de la destrucción de África, cap. 9 (= Hist. Indias, I 25), op. cit., pp. 252-257.

8 Las Casas, B., Historia de Indias, lib. 3, cap. 102 (edición de Agustín Millares Carlo y estudio preliminar de Lewis Hanke, [1951] $2^{\mathrm{a}}$ reimpr., México, FCE, 1986, vol. 3, p. 177).

9 Sото, D., Relectio de dominio, n. 25 (Relecciones y opúsculos, vol. I, edición de Jaime Brufau Prats, Salamanca, San Esteban, 1995, pp. 150-151).

10 Sото, D., De iustitia et iure, lib. 4, q. 2, art. 2, Secunda conclusio (versión española de Marcelino González Ordóñez, Madrid, IEP, 1968, tomo 2, p. 289). 
negros de Cabo Verde» ${ }^{11}$. Comienza por afirmar la legitimidad de la esclavitud como institución reconocida por el derecho de gentes y prosigue analizando cada uno de los títulos aplicados a las circunstancias de la realidad, debilitando la consistencia de los mismos. Después de todo lo señalado, sin embargo, no concluye rechazando la institución ni siquiera la trata en general, sino que reprueba los comportamientos descuidados:

«Esta práctica entendida digo, en lo que toca al derecho, dos conclusiones. La primera, que la venta y compra de negros en Cabo Verde es de suyo lícita y justa. La segunda, que supuesta la fama que en ello hay, y aun la realidad de verdad que pasa, es pecado mortal, y viven en mal estado, y gran peligro los mercaderes de gradas, que tratan en sacar negros de Cabo Verde. La razón es estar este trato tan infamado, y ser pública voz, que a muchos dellos se les hace fuerza, y violencia. Por lo cual sólo están los de acá obligados a no meterse en ello, por no participar de la injusticia (...) Cuando una persona está infamada que lo que trae de fuera a vender, es mal habido, obligados están los vecinos a no mercarle cosa, no obstante que muchas veces a vueltas traigan lo que realmente es suyo, y posee con buen título, mas aquella mala opinión, supuesto ser bien fundada, no sólo malas lenguas, basta, y aun obliga a no tomarle nada, so pena de perderla si pareciere su dueño. Los portugueses que tratan en Cabo Verde, y traen negros de Santo Tomé de Biafra, Zape y Jolofe, y los mismos etíopes que los venden, están infamados como todos sabemos, que muchas veces los han mal, y por mal cabo. A cuya causa es menester, los de acá, sino quieren comunicar en el pecado se sobresean, y aparten del contrato y venta (...) Así diciéndose en público (como se dice) que gran parte de los negros que se sacan, vienen cautivos contra justicia, no se pueden mercar, ni entremeter nadie en semejante negociación (so pena de pecado, y restitución) $»^{12}$.

Cuatro años después de la publicación de la primera edición de la muy difundida Suma de tratos y contratos de Tomás de Mercado, antes referida, apareció impreso el Arte de contratos (Valencia, 1573) de Bartolomé de Albornoz, vecino de la villa de Talavera de la Reina y que llegó a ser el primer catedrático de Derecho civil en la recién fundada Universidad de México en 1553. En esa obra su autor repasa los argumentos sobre la esclavitud y amplía los datos sobre la captura de negros. Al respecto, los comentarios más interesantes están localizados dentro de la digresión con la que se explaya al tratar de las mercaderías y los contratos cambiarios, pues ahí se pronuncia sobre las dudas de conciencia en la compra de esclavos negros ${ }^{13}$.

11 Mercado, T., Suma de tratos y contratos (1569; segunda edición definitiva 1571; edición y estudio introductorio por Restituto Sierra Bravo, Madrid, Editora Nacional, 1975), lib. 2, cap. 20, pp. 275-282.

12 Ibid., pp. 279-280.

13 Albornoz, B., Arte de los contratos, Valencia, Pedro de Huete, 1573. Interesa especialmente el lib. 3, tít. 4, desde los folios 130 rectus hasta el 131 rectus. Sobre Bartolomé de Albornoz hace una escueta alusión Domínguez OrTiz, A., "La esclavitud en Castilla durante la Edad Moderna», op. cit., pp. 43-45; más ilustrativos son Alonso Rodríguez, B., "Notas al "arte de los contratos" de Bartolomé Frías de Albornoz (1573)», Salmanticensis, 21 (1974), pp. 
Albornoz hacía una diferencia entre los esclavos procedentes de los continuos conflictos entre cristianos y musulmanes en el entorno del mar Mediterráneo y los esclavos procedentes de los territorios africanos explorados por los portugueses. Los primeros son los negros moros, descritos como negros de un color leonado semejante al color del membrillo cocido. Sobre estos no hay disputa porque son infieles, la esclavitud es admitida recíprocamente como represalia por guerra justa y se rige por los criterios del derecho de guerra ${ }^{14}$. El problema era sobre los negros etíopes. No hay un rechazo general basado en el reconocimiento de la igualdad fundamental de los seres humanos, sino una especie de prejuicio racial y geográfico, como dice Tellkamp, que restringe la esclavitud de los moros por las molestias que ocasiona su agresividad, peores que un basilisco o un tigre. Hay un tajante rechazo a los que abusan de esta gente y fletan barcos para secuestrarlos. Y también es tajante su rechazo a la compra de esclavos a los traficantes portugueses, porque estos no obran con justicia aunque lo parezca. Esto debía decirse con cautela porque la venta reunía los requisitos legales en cuanto que gozaba de la autorización del rey de Portugal. Aun así Albornoz no acaba de creer la validez de los tres títulos que solían aducirse: ni guerra justa, ni respeto de las leyes internas de los territorios de origen, ni venta por hallarse en extrema necesidad:

«Quien quisiere ver algunas causas que hay para la justificación de la servidumbre, vea las que pone el Maestro Mercado en su tractado (puesto que no muestra mucha satisfacción dellas) y yo me satisfago mucho menos, de las que a él le parecen justas, que de las que confiesa que no lo son (...), destas digo como de todo lo demás, que deben de ser buenas; pues que yo no las entiendo ${ }^{15}$.

Mientras que Mercado condenaba la primera compra de los negros capturados injustamente, la peculiaridad de Albornoz es que extendía la

457-467; Alonso Rodríguez, B., «El Doctor Bartolomé Frías de Albornoz, primer catedrático de Instituta en la Universidad de México», en García SÁnchez, J. et al. (coord.), Estudios in memoriam del profesor Alfredo Calonge, Salamanca, Asociación Iberoamericana de Derecho Romano, 2002, vol. 1, pp. 43-59; Esponera CERdán, A., "Teoría anti-esclavista de Bartolomé Frías de Albornoz», en Ética y teología ante el Nuevo Mundo. Actas del VII Simposio de Teología Histórica, Valencia, Facultad de Teología San Vicente Ferrer, 1993, pp. 93-114; y sobre todo García AÑoveros, J. M., «Bartolomé de Frías de Albornoz», en Murillo, I. (Ed.), El pensamiento hispánico en América: Siglos XVI-XX, Universidad Pontificia de Salamanca, 2007, pp. 531-562. Jesús M ${ }^{a}$ García AÑoveros (ibid., pp. 538-539) deja asentado que Bartolomé de Albornoz no fue clérigo o dominico, sino un seglar que contrajo matrimonio en México, tal como se infiere de la carta escrita en 1565 por el visitador Jerónimo de Valderrama.

14 Tellkamp, J. A., "Esclavitud y ética comercial en el siglo XVI», Anales del Seminario de Historia de la Filosofía, 21 (2004), pp. 135-148 (sobre Mercado y Albornoz). Sin embargo, el texto que cita de Albornoz (ibid., p. 144) no se refiere a los negros africanos o etíopes, de los cuales se dice algo muy distinto, sino que alude a cautivos de guerra, sobre los que ya he indicado que no había disputa porque estos son enemigos de la monarquía hispánica y de la cristiandad (caso de los negros moros).

15 Albornoz, B., Arte de los contratos, lib. 3, tít. 4, fol. $130 \mathrm{v}$. 
ilegalidad a todas las transacciones sucesivas. Ciertamente que Albornoz presenta la crítica como una digresión que ofrece a los lectores, en particular a los mercaderes traficantes de esclavos, a modo de consejo y no de precepto.

Por su lado, el jesuita Luis de Molina (1535-1600) dedicó más extensión que otros a considerar la esclavitud en el tratado segundo De iustitia et iure, sobre la justicia conmutativa acerca de los bienes externos, en el que además incluye abundantes detalles sobre los diferentes orígenes geográficos de los esclavos o la diferente credibilidad de los títulos de esclavitud según los lugares de procedencia, amén de avanzar una especie de sociología política de las jefaturas africanas ${ }^{16}$.

Molina cuenta con una minuciosidad extraordinaria el procedimiento de captura de los pobres negros, las artimañas que empleaban contra ellos sus mismos jefes tribales; describe las costumbres de los poblados africanos y los escenarios de la trata, pasando desde Guinea, Cabo Verde, la costa de Santo Tomé, el Congo, Angola, hasta los escenarios de la India, China y Japón ${ }^{17}$.

Respecto de la situación de los esclavos procedentes de ambas Guineas, sostenía la licitud de comprar al que había sido condenado por la autoridad pública correspondiente por algún crimen suficiente, pero a los familiares del condenado solamente sería lícito comprarlos cuando la condena hubiera sido por crimen atroz ${ }^{18}$.

La regla que fija Molina para asegurar la venta y la conciencia de los mercaderes es que esa condena a la esclavitud solo sería admisible por crímenes graves, que fueran equivalentes a los que entre nosotros se castigarían con pena perpetua de galeras, o a una pena un poco inferior. Este criterio resulta del intento de comparación estableciendo la equivalencia del bien jurídico protegido atendiendo al elemento cuantitativo de la sanción. Los ejemplos que serían aceptables, en el contexto de la época, eran los delitos de adulterio, atentados

16 Habitualmente ha solido pasar desapercibida esa información etnográfica o sociológica, aunque algunos historiadores actuales se han sorprendido al encontrarla, por ejemplo Hespanha, A. M., "Luis de Molina e a escravizaçao dos negros», Análise Social, vol. XXXV, núm. 157 (2001), pp. 937-960; Сохіто, A. A., «Luis de Molina e a escravatura», Revista filosófica de Coimbra, vol. 8, N. 15 (1999), pp. 117-136; García AÑoveros, J. M., «Luis de Molina y la esclavitud de los negros africanos en el siglo XVI. Principios doctrinales y conclusiones», Revista de Indias, vol. 60, núm. 219 (2000), pp. 307-329. No ha enfatizado los aspectos sociológicos, en cambio, BRIESKORN, N., "Die Sklaverei in der Beurteilung des P. Luis de Molina S. J.», en MeIer, J. (Hg.), «...usque ad ultimum terrae»: Die Jesuiten und die transkontinentale Ausbreitung des Christentums 1540-1773, Göttingen, Vandenhoeck \& Ruprecht, 2000, pp. 85-98.

17 Molina, L., De iustitia et iure, tr. 2, disp. 32-40. Esta obra se editó en Cuenca en 1593-1600, pero la primera parte tal vez fuera explicada en Coimbra o en Évora durante su periodo docente, desde 1566 hasta 1590. Probablemente esa descripción tan desenvuelta de las costumbres africanas se preparó en el contexto de las aulas universitarias como un apéndice destinado a la enseñanza, pues en la edición impresa esa parte escrita resalta por su plasticidad. Coincidimos con la apreciación de António M. HespanHa (op. cit., p. 937), que destaca el «carácter articulado y desenvuelto» de esta parte del tratado.

18 Molina, De iustitia et iure, tr. 2, disp. 35, n. 6. 
contra el pudor o robo de cosas importantes. Aquí muestra Molina su extrañeza de que se pueda condenar a esclavitud por el robo de una gallina o de objetos insignificantes; no obstante admite una posibilidad que lo hiciera comprensible: «a menos que entre ellos exista la experiencia de que solo así se contienen los robos». Este motivo explicaría, en su opinión, que se castigara tan fuertemente robos aparentemente nimios, de modo similar a lo que sucede también en los países europeos que castigan con penas graves robos producidos en el ejército ${ }^{19}$.

Parece Molina mostrarse comprensivo con las prácticas culturales africanas y encuentra una funcionalidad al sistema sancionador extranjero, pero en último término esta incipiente asunción de la pluralidad cultural suelda la esclavitud real a la situación socioeconómica existente. El análisis de Molina es característico de la mezcla entre la irritación por el modo inhumano en que se trata a los africanos y la aséptica aceptación de la realidad encubierta con la burocrática supervisión de las autoridades regias y eclesiásticas.

\section{La opinión de SuÁrez Sobre la trata de negros}

Tras el sucinto muestreo de los más relevantes doctores de la primera modernidad concernidos por la persistencia de esa peculiar institución de la esclavitud, tenemos ahora la oportunidad de recoger a continuación lo que escribió al respecto Francisco Suárez (1548-1617) y lo que otros coetáneos importantes le atribuyen. ¿Qué sabemos de su opinión sobre la esclavitud y venta de los negros?

Suárez había descartado el asunto con el solo reconocimiento de que hay muchas dudas al respecto de tema tan debatido. Eso es cuestión grave, magna est quaestio. Según escribe, no correspondía ocuparse de ello en aquel lugar del comentario a la tercera parte de la Summa Theologiae de Santo Tomás donde aparece la escueta mención anterior, ocupado el autor de explicar el bautismo de los párvulos y de la potestad de bautizarlos:

«Por último, en general hay que entender que solo son propiamente esclavos los infieles capturados en guerra justa, que usualmente son sarracenos, turcos y demás, o los que se compran por un precio a sus verdaderos dueños que tienen el derecho de venderlos. Sobre estos hay una controversia muy grande, que no concierne a este lugar, porque aquí no tratamos de cuándo alguien se hace legítimamente esclavo, sino de cómo pueda dársele el bautismo, supuesto un dominio sobre él tal como se tiene sobre un esclavo» ${ }^{20}$.

19 Molina, De iustitia et iure, tr. 2, disp. 35, n. 6 (Moguntiae, sumptibus Hermanni Mylii Birckmanni, 1614, col. 181-182).

20 SuÁrez, De sacramentis, disp. 25, sect. 5, n. 9 (Opera omnia, París, Vivès, 1860, tomo 20, p. 443): «Deinde generaliter dicendum est, eos tantum infideles esse proprie servos, qui vel iusto bello capiuntur, ut sunt ordinarie Saraceni, Turcae, etc., vel qui pretio emuntur a veris dominis, qui ius habent illos vendendi; de quibus magna est quaestio, quae ad hunc locum non spectat; nam hic non tractamus, quando aliquis legitime fiat servus, sed quomodo possit illi baptismus dari, supposito dominio in eum, tanquam in servum». 
Creo que podríamos calificar esta mención como una referencia mínima, incidental y timorata. Precisamente sobre esa cuestión omitida se centraba la discusión doctrinal y las posiciones oscilaban entre quienes manifestaban pocas dudas sobre el título originario y los que mostraban las más severas reconvenciones y dudas sobre la justicia del título originario. En cualquier caso, todos admitían la legitimidad de la esclavitud y la validez de las transacciones.

Las dudas de que los esclavos no fueran tales sino personas libres que habían sido engañadas, robadas, secuestradas o condenadas injustamente a la esclavitud por delitos inexistentes o levísimos, estas dudas de conciencia, podían erosionar la validez de la compraventa posterior en los mercados europeos. Pero en la medida en que el segundo y posteriores compradores no podían verificar por sí mismos las circunstancias que en el lugar de origen habían convertido al sujeto vendido en esclavo, tenían que fiarse de la declaración de los mercaderes y las autoridades regias.

Las dudas probables no invalidaban la venta, pues la presunción operaba en el sentido de mantener la seguridad jurídica de la transacción: en caso de duda se mantiene la situación del poseedor actual (principio possidentis). También, creo yo, conduce a la misma solución, o podría apoyarla, el principio tutior pars, pues la solución más segura está favorecida por la eficacia de los procedimientos legales, la intervención administrativa y el pago de tasas e impuestos.

Solamente cuando existiera la convicción plena de que la venta era injusta y que el esclavo había sido privado injustamente de su libertad, se propugnaba declarar nula la compraventa y restituir la libertad e indemnizar al sometido injustamente. Pero en la práctica no se concretaron esas exigencias legales cuya extensión podría haber ocasionado la nulidad de todas las ventas de esclavos, o de la gran mayoría de ellas. Ni siquiera a finales del siglo XVIII fueron coherentes con sus proclamas de igualdad universal los revolucionarios franceses, que en la Declaración de derechos del hombre y del ciudadano, excluyeron a los esclavos de las colonias ${ }^{21}$; y en Norteamérica el presidente Jefferson afirmaba la igualdad de derechos inalienables de todos los seres humanos, al mismo tiempo que excluía de la libertad a los negros, rechazaba la coexistencia mezclada de las razas y pretendía la gradual emancipación de los esclavos y su deportación a África ${ }^{22}$. En España, durante el estadio liberal el abolicionismo suscitó extraordinario encono y resistencia en las Cortes de

21 Gainot, B. et al., "Lumières et esclavage», Annales historiques de la Révolution française, vol. 380, núm. 2 (2015), pp. 149-169; Piquet, Jean-Daniel, L'émancipation des Noirs dans la Révolution française (1789-1795), París, Éditions Karthala, 2002, pp. 17-36 sobre las ambigüedades de los enciclopedistas; EHRARD, Jean, Lumières et esclavage. L'Esclavage colonial et l'opinion publique en France au XVIII ${ }^{e}$ siècle, París, André Versaille, 2008.

22 Vid. Aparisi Miralles, A., "Thomas Jefferson y el problema de la esclavitud», Anuario de Filosofía del Derecho, 7 (1990), pp. 455-468; CoHen, W., «Thomas Jefferson and the Problem of Slavery», History, vol. 56, n. 3 (1969), pp. 503-526; Finkelman, P., «Thomas Jefferson and Antislavery», The Virginia Magazine of History and Biography, vol. 102, N. 2 (1994), pp. 193-228. 
Cádiz, sobre todo por parte de los propietarios cubanos que dependían del trabajo esclavo para los ingenios del azúcar ${ }^{23}$.

Incluso en la esclavitud por necesidad, presumiendo voluntaria la venta de uno mismo o de los hijos por sus padres, puede acontecer que alguien quiera remediar su grave necesidad entregándose a otro que puede causarle tanto daño o perjuicio en el futuro como daño actual le causa la necesidad presente. Sin embargo, la presunción de legalidad podría impedir que prevalezca la libertad en caso de duda irresoluble, porque operan simultáneamente los dos criterios argumentativos que guían la ponderación: la solución tutior está del lado de la validez del contrato amparado legalmente, y a la vez el poseedor del derecho dominical tiene la libertad transferida por el esclavo, que ya no posee en la actualidad su libertad. Todos ellos actúan como principios que apoyan una solución u otra según convenga, no son reglas inflexibles que actúan rígidamente siempre y en todo caso.

Suárez habría callado cuando tuvo oportunidad de escribir algo sobre la controvertida cuestión jurídico-moral de la legitimidad de los títulos de esclavitud de los negros africanos. Sin embargo, otros autores que opinaron específicamente sobre el comercio de esclavos negros apoyaron algunas aseveraciones acudiendo a Suárez. Algunos de estos personajes de relieve escribieron con posterioridad al momento en el que presumiblemente Suárez habría tenido ocasión de pronunciarse, desde Junio hasta finales de Agosto de 1584, sobre todo cuando impartía sus lecciones romanas en materia de justicia ${ }^{24}$.

Las referencias que se hacen a la postura del padre Suárez provienen de colegas suyos, de Avendaño y Solórzano Pereira. Estos conocen la opinión de Suárez sobre los negros por vía de su hermano de religión, el jesuita portugués Fernando Rebello, que es la fuente original de atribución. Hasta el presente no se había destacado lo suficiente esta relación, que sepamos. Además, muy poco después Suárez y Avendaño recibirán una fuerte reprimenda de Epifanio Moirans, fraile capuchino que junto con su colega Francisco de Jaca han sido presentados en la actualidad como los primeros defensores hispánicos de los negros.

No hemos podido encontrar en las obras de Suárez la opinión que se le atribuye, con el objeto de verificar la autoría. No obstante, importa aquí señalar cómo fue leído Suárez y utilizadas sus sentencias por los coetáneos como fuente segura en materias controvertidas.

23 Álvarez Alonso, C., "Libertad y propiedad. El primer liberalismo y la esclavitud», Anuario de Historia del Derecho Español, 65 (1995), pp. 559-583; MARTínez DE Pisón, J., «El debate abolicionista en el primer liberalismo español», Cuadernos Electrónicos de Filosofía del Derecho, 35 (2017), pp. 90-115. La abolición definitiva de la esclavitud en los territorios españoles de ultramar se produjo en 1873 para Puerto Rico, y en 1886 para Cuba.

24 Rodríguez, F., «La docencia romana de Suárez (1580-1585)», Cuadernos Salmantinos de Filosofía, 7 (1980), pp. 308-311. 


\subsection{El dicterio de Moirans contra Suárez y Avendaño}

El borgoñón Epifanio Moirans (1644-1689) reconoció incidentalmente que era costumbre que los pueblos cristianos entablasen guerras justas con enemigos de otras creencias, de modo que sería admisible esclavizar al cautivo de guerra en esos casos, pero esta circunstancia no era aplicable a los negros de su tiempo:

«Pero los negros no son enemigos de los cristianos; es más, muchísimos son cristianos. Luego no pueden los cristianos hacerlos esclavos; con mucha más razón no pueden apresarlos con engaño, fraude, rapiña, ni comprarlos injustamente y contra el derecho natural por quienes adquieren negros, como ocurre hoy $)^{25}$.

Por consiguiente, admitía la esclavitud como reparación por la guerra justa, criterio que se mantendrá todavía hasta que un siglo después Rousseau formule su rechazo radical de la esclavitud. Pero Epifanio de Moirans avanza en el desmontaje de los títulos que se alegaban para fundamentar la esclavización de los negros y al hacerlo va criticando acerbamente a sus célebres precursores que, a pesar de dudar y de mostrar muchas cautelas, sin embargo eran en definitiva complacientes. En particular, la crítica se dirige contra la autoridad de los jesuitas Luis de Molina, Fernando Rebello, Diego de Avendaño y Francisco Suárez.

La mención a Suárez procede del apoyo que éste había proporcionado a Diego de Avendaño (1594-1688) ${ }^{26}$, quien a su vez lo había citado en una breve nota de su Thesaurus Indicus. Este teólogo segoviano que emigró muy pronto al Perú se había referido a Suárez en un escueto párrafo:

«Igualmente, debido a que muchos son comprados para trabajar en las minas de oro y plata, trabajo que no pueden sobrellevar y al que - por más que sean dignos de muerte- no puede condenárseles. Añade [el Padre Fernando Rebello], tomándolo del P. Suárez, que la compra para dicho trabajo puede ser lícita, si tal trabajo se les compensa con algún salario justo, y se les proporciona el que puedan respirar cómodamente en la navegación. Esto puede sostenerse debido al gran bien que ello proporciona a todo el orbe, al obtener oro y plata que aprovecharán a todos. Esto lo explica el sabio Padre más extensamente $»^{27}$.

Avendaño reprodujo textos de Suárez procedentes del tratado sobre los sacramentos, en especial De baptismo, allí donde Suárez disputaba sobre la colisión entre el deber de evangelizar al infiel y el derecho paterno.

Así que Moirans reprochará a Diego de Avendaño y a Francisco Suárez que defendieran la licitud de la compra de esclavos para trabajar en las minas por

25 MoIRans, E., Siervos libres. Una propuesta antiesclavista a finales del siglo XVI, edición crítica bilingüe por M. A. Pena González y la traducción y colaboración de T. de Azcona, J. Labiano, C. Baciero y J. M Soto, Madrid, CSIC (CHP-Segunda Serie, vol. 14), 2007, cap. 3, n. 43, p. 63.

26 Moirans, E., Siervos libres, cap. 9, n. 93 y 96.

27 Avendaño, D., Thesaurus Indicus, tit. 9, cap. 12, § 8, n. 196 (Avendaño, D., Corregidores, encomenderos, cabildos y mercaderes. Thesarus Indicus, vol. I, Tit. VI-IX, edición de Ángel Muñoz García, Pamplona, Eunsa, 2007, p. 464). 
la utilidad o beneficio universal de los metales extraídos. Moirans rebate esa opinión porque nunca habría compensación equivalente de un trabajo tan insoportable, extraordinario y peligroso ${ }^{28}$.

Descalifica la opinión de Suárez como una serie de teorías imposibles de llevar a la práctica, insistiendo en que de ninguna manera es lícito condenar a los esclavos a trabajar siempre y no educarlos en la fe. Eso era inhumano y cruel. En ningún caso podría afirmarse que ese comportamiento aberrante es útil para todo el mundo, ni siquiera compensándoles por esos servicios extraordinarios y peligrosos. Y concluye, encarándose con las voces autorizadas:

«Y dice Suárez que por la gran utilidad para todo el mundo, se los puede comprar para dicho trabajo, si se les da una justa compensación y en tanto se les provea en la navegación. Una cosa querría preguntarle a él y a Avendaño, quien dice que ellos mismos considerarán irracional oponerse. La pregunta es esta: ¿querrían ellos mismos con el título justo de esclavo ser comprados para tal trabajo supuesta dicha compensación y que se les provee en la navegación para que puedan rehacerse, a cambio de la gran utilidad para el mundo entero? Si en modo alguno, ¿cómo se atreven a obligar a otros a ello? ${ }^{29}$.

\subsection{Fernando Rebello: la cláusula compensatoria suareciana}

De Avendaño había tomado la información Moirans, acabamos de exponerlo, pero la referencia que aquél hace a Suárez había sido tomada, según muestra la nota de autoridad, a través del padre Fernando Rebelo.

Fernando Rebello o Rebellus (1546-1608), nació en el pueblo portugués de Prado, situado en la diócesis de Lamego e ingresó en la Compañía de Jesús en Lisboa el 20 de Mayo de 1562. Enseñó durante seis años filosofía y doce teología en Évora. Difusor del pensamiento de Aristóteles ${ }^{30}$, realizó estancias

28 Moirans, Siervos libres, cap. 9, n. 99 (op. cit., p. 151): «Digo, lo tercero, (...) que están obligados a liberar cuando no puedan indagar la verdad del justo título de esclavitud, sea buena o mala fe con que compraron. Ahora bien, no pueden indagar esta verdad, como es manifiesto por lo que ellos mismos han dicho [Rebello y Avendaño] y como es moralmente cierto. Luego están obligados a liberar a todos los esclavos.// De esta manera quedan justificadas las conclusiones apuntadas en el argumento del libro desde los mismos adversarios. Pero lo que añade sobre el padre Suárez no se sostiene. Porque ¿qué compensación podría hacerse a los esclavos por tales servicios tan extraordinarios y peligrosos, a los que no se condena sino a los reos de muerte, como dicen Rebello y Avendaño? Además de que, como siempre trabajan día y noche, la compensación no se ofrecerá en la disminución de los trabajos; debería hacerse, por tanto, sea en el precio o en alguna mejora del trato por estos trabajos en cuanto a comida. Pero de cualquier modo que se hable, nunca esa compensación es equivalente; pues ¿qué aprovecha todo lo dado y cualquier buen traslado, si siempre sigue sujeto a un trabajo insoportable, extraordinario y peligroso, como dicen ellos mismos?».

${ }_{29}$ Ibid., p. 151.

30 Cadafaz de Matos, M., «Cultura e língua grega em Portugal e outras regiões da península entre os séculos XV e XVIII (seis momentos para a compreensão e estudo da sua dinâmica)», Revista Portuguesa de História do Livro, 24 (2009), p. 278: intentó difundir textos de Aristóteles, como la Metaphysica este jesuita y humanista portugués, Fernando Rebelo. 
en Lisboa y Roma, adonde fue reclamado para enfrentarse a los excesos del probabilismo, pero su desempeño fundamental transcurrió en la cátedra de la Universidad de Évora, de la que fue también Canciller durante ocho años ${ }^{31}$. Precisamente firmó como canciller cuando le confirieron a Suárez el grado de doctor el 4 de junio de 1597, expidiéndole la carta doctoral al día siguiente ${ }^{32}$.

Una de las cuestiones de que se ocupa Rebello en la primera parte introductoria de su libro sobre las obligaciones de justicia, es acerca del dominio sobre esclavos y otra acerca de los diferentes modos en que se esclaviza a los negros. Después resume las opiniones recientes, exponiendo su propio criterio al respecto de la compraventa de los etíopes ${ }^{33}$. Es en este contexto donde recurre a la sentencia de Suárez en apoyo de su propia postura.

Empieza describiendo el parecer de quienes ven justa la compra de esclavos negros en Angola, porque allí era costumbre que también el rey local poseyera esclavos en algunas de sus aldeas llamadas morindas. Esos reyezuelos mandaban en un territorio donde hay poblados con aldeas a modo de fortalezas habitadas por una clase social de esclavos, gente sometida desde tiempo inmemorial, durante generaciones y por derecho hereditario.

Aunque ocurriera que estos siervos fueran vendidos por sus dueños legítimos, que en efecto poseen título válido de esclavitud desde hace tan largo tiempo, el problema estriba en cohonestar esa situación con la venta que se hace a los mercaderes en Angola y Guinea para exportar los esclavos hacia las minas auríferas y de plata en las Indias occidentales. Aquí centra la cuestión Rebelo. El

Hoy se sabe que las dos versiones aristotélicas de Rebelo fueron realizadas casi nueve años después de que hubiera ingresado en el Colegio de San Roque de la Compañía de Jesús, en Lisboa, en 1562 y después de haber entrado como profesor en funciones, en octubre del mismo año, en la Universidad de Évora.

31 Castellanos de Losada, B. S. (dir), Bibliografía eclesiástica completa, Madrid, Imprenta de D. Alejandro Gómez Fuentenebra, 1864, tomo 20, pp. 1007-10, s. v. «Rebello o Rebellus, Fernando»; Hurter, H., Nomenclator literarius Theologiae Catholicae aetas recens. Post celebratum concilium tridentinum, $3^{\text {a }}$ ed., Geniponte, Libraria Academica Wagneriana, 1907, T. 3, col. 598; Barrientos García, J., Un siglo de moral económica en Salamanca (1526-1629), Pamplona, Eunsa, 1985, pp. 357-358. Obra importante de Rebelo: Opus de Obligationibus iustitiae, religionis et caritatis, Lugduni, Horatii Cardon, 1608. Fue después publicada en Venecia en 1610. Esta obra debía haber tenido cinco partes: tres sobre la justicia, las otras dos sobre la religión y la caridad, en dos volúmenes pero apareció solo el primero. Más datos en el Diccionario histórico de la Compañía de Jesús, vol. 4, Roma-Madrid, Universidad Pontificia de Comillas, 2001.

32 El pergamino que contiene la Carta doctoral, fechada el 5 de junio de 1597, fue firmado por el Rector Pedro Novais, el Canciller Fernando Rebello, el lector de Escritura Bras Viégas y los lectores de Teología Esteban Couto, Cristóbal Gil y Pedro Luis. Tomamos esta información de García Ribeiro de Vasconcellos, A., Francisco Suárez Doctor Eximio (Colleçâo de Documentos), Coimbra, Imprensa da Universidade, 1897, pp. 48-49.

33 Rebello, F., Opus de Obligationibus iustitiae, religionis et caritatis, (Lugduni, Horatii Cardon, 1608), Prima pars, lib. 1, quaestio 9: «De dominio mancipiorum. Quibus modis homines serviant»; quaestio 10: «Sitne licita apud nos in Lusitania Æthiopum emptio ac possessio?». La q. 10 tiene dos secciones: q. 10, sectio 1: «Quid recentiores censeant et qua ratione ab aliis licita putetur»; q. 10, sectio 2: «Sententia Auctoris quoad Aethiopum emptionem». 
destino de los esclavos es parte del problema, porque el traslado en barco ocasiona un peligro para la vida tan grande, así como los trabajos a que van destinados son tan inhabituales y causan tanta aflicción, que muchos mueren en poco tiempo. Rebelo encuentra difícil excusar esa venta para tal finalidad, a no ser con una limitación que poco más abajo reconoce. Esta limitación es la que supuestamente había añadido Suárez, que es por lo tanto la fuente de autoridad primordial.

Reconstruyamos el núcleo de la discusión y la importancia de la supuesta aportación suareciana. El problema reside en el desbordamiento del contenido esencial de la institución «esclavitud» que alcanza a exigir los servicios debidos, mientras que el trabajo en las minas, en galeras u otros similares, desborda los estándares de normalidad por el evidente peligro para la vida que conllevan. Desborda el poder ordinario de los amos, aunque prometan compensarles con la liberación. No son trabajos corrientes y consta que nunca han sido realizados para el rey de Angola por sus propios esclavos, ni por sus progenitores. Es tan intolerable destino que los plagiarios (ladrones de esclavos) que secuestran a hombres libres o a esclavos ajenos son condenados a trabajos forzados en las minas como reos de crimen capital ${ }^{34}$.

Aquí viene el modo suareciano que permite comprar esclavos para mineros, la cláusula compensatoria. Reproduciremos el texto por su especial interés y difícil localización:

«Por lo cual, aunque en Angola existan plazas fuertes con esclavos en cada una de las Morindas, que desde su nacimiento pertenecen por derecho hereditario al rey y los régulos, no por ello será lícita su compra, si se los compra para extraer oro o plata, por las razones antedichas. A no ser, como nuestro Suárez limitaba, que se diera alguna justa compensación por esos servicios tan extraordinarios y peligrosos, que para cualquiera sería irrazonable rechazarlos. Esto es, como si les redujera la duración de la esclavitud tanto tiempo cuanto mayor sea el exceso y la dificultad de los servicios, valorando la rebaja a juicio de prudentes, concediéndoles al final la libertad y otros premios.

Además, habrá que proveer a estos en su travesía de remedio para el peligro cierto que arrostran contra su vida, para que no mueran encerrados en las bodegas de las naves asfixiados con su hedor, al negarles la respiración de aire puro. El citado Doctor consideraba que había de ser permitida [la compra de estos esclavos] con esta siguiente limitación: por el bien común, pues de no ser así, por causa de la escasez de operarios en las minas auríferas, no solo España sino casi todo el orbe estarían privados del uso de oro y plata y de las perlas. Aunque la compra antedicha no sería ilícita en cuanto a estos que por

34 Rebello, F., Opus de Obligationibus iustitiae, religionis et caritatis, Prima pars, lib. 1, q. 10, sect. 2, n. 19 (fol. 72 B-C). Con apoyo en el Código de Justiniano, l.ultima, ad legem Fabiam (C. 9, 20, 16): «Plagiarii, qui viventium filiorum miserandas infligunt parentibus orbitates, metalli poena cum ceteris ante cognitis suppliciis tenebantur. 1. Si quis tamen eiusmodi reus fuerit oblatus, posteaquam super crimine patuerit, servus quidem vel libertate donatus bestiis obiciatur, ingenuus autem gladio consumatur». 
un delito son reducidos justamente a esclavitud, si el crimen fuese digno de tanto suplicio. Esto en cuanto a los esclavos de Etiopía» ${ }^{35}$.

Sin embargo, Rebello tampoco señala el lugar específico donde Suárez justificaría la adquisición de esclavos. Es cierto que este jesuita portugués utiliza en su tratado principalmente dos obras de Suárez para otras ocasiones sobre la obligatoriedad de las promesas o los tipos de justicia. Son estas obras el opúsculo De iustitia Dei y una relección De promissione. Probablemente se reproducían las fuentes sin verificarlas directamente, pero en esta ocasión la afirmación es seria como para que se hubiese atestiguado indubitablemente dónde Suárez aceptaba la compra de africanos aunque hubiese sospechas fundadas de la injusticia originaria.

Si ampliamos nuestra investigación hasta las obras del prestigioso jurista madrileño Juan de Solórzano Pereira (1575-1653), este también se remitirá a la opinión de Suárez y de Rebello. Solórzano es el gran jurista del Derecho indiano, un jurista muy erudito y con extensa carrera funcionarial, Oidor de la Audiencia de Lima, Consejero de Estado y de Indias. La referencia se hace en la nota que indica simplemente que la información expuesta por él ha sido tomada de Rebello. Está contenida en la Política indiana, obra que fue editada por primera vez en 1647, y ha tenido numerosas reediciones y traducciones. El texto concreto aparece cuando Solórzano escribe de las minas, bien conocidas por él porque había sido inspector. Reconoce que eran peligrosas pero necesarias «y más en tiempos de tan urgentes necesidades», que debían labrarse por modos y medios suaves, lícitos, para fundar y asegurar la abundancia. Y añade que esa es la manera adecuada de explotarlas, como se hacía ya en su época, mejorando las condiciones de seguridad y licitud:

«Como será labrándolas con esclavos comprados y diputados para este servicio, lo cual debajo de ciertas condiciones tienen por lícito y honesto los doctos y religiosos Padres Francisco Suárez y Fernando Rebelo, y no solo lo encargan y mandan sino también muestran desearlo sumamente las muchas Cédulas Reales que dejo citadas en los capítulos precedentes, y en especial las que llaman del servicio personal del año 1601 y $1609 »^{36}$.

\section{3. ¿Quién es «nuestro Suárez»?}

Ha habido dudas sobre la personalidad del tal Suárez que se menciona, tomado de referencias tan indirectas y sin amparo de ningún título de obras o escritos en que haya publicado tal interpretación ${ }^{37}$.

35 Rebello, F., op. cit., Prima pars, lib. 1, q. 10, sect. 2, n. 21 y 22 (fol. 72 E-73 A).

36 Solórzano Pereira, J., Política indiana, lib. 2, cap. 17, n. 22 (Madrid, Imprenta Real de la Gazeta, 1776, tomo 1, p. 143). La nota $b$ ) solamente repite: «Suarez quem refert, \& sequitur Rebel.de oblig.iust.lib. I quest. 10 n. 12». Hay errata en el número de párrafo de la obra de Rebelo, que es n. 21.

37 José Tomás López García duda de quién pueda ser este Suárez: «No sabemos realmente de qué P. Suárez se trata, porque Fr. Epifanio no pone ninguna otra referencia». Vid. López García, J. T., Dos defensores de los esclavos negros en el siglo XVII, op. cit., p. 93 nota 170 a. No va más allá en el rastreo de las fuentes. 
Por consiguiente Fernando Rebelo es la fuente primaria de atribución de la autoría a Suárez y la información pasa de él a Diego Avendaño, y a través de éste a Moirans y a Solórzano. Fernando Rebello solamente menciona dos autores con el apellido Suárez: uno es el teólogo jesuita Francisco Suárez y otro el jurista portugués Enmanuel o Manuel Suárez de Ribera. Sería posible que hubiera citado de manera incompleta a ambos Suárez, aunque sabemos que para referirse al segundo suele citarlo como Suárez de Ribera, o «Suárez a Rivera». Es lógico, entonces, suponer que cuando escribe «nuestro Suárez», noster Suarez, hace referencia al compañero de orden, pues Rebello también era jesuita. Aparece varias veces como «noster Franciscus Suáres», acompañando al margen la referencia a De iustitia Dei, que es un opúsculo indubitado de nuestro jesuita granadino, otras escribe «ut noster Suarez» ${ }^{38}$.

Pero hay otro elemento más a favor de considerar que el autor mencionado es el teólogo, pues Rebello se refiere a él como «P. Suárez», y no hay otro padre Suárez que el teólogo español.

\section{LA LEGITIMIDAD DEL TÍTULO ORIGINARIO DE ESCLAVITUD}

Suárez acepta la esclavitud de los negros suponiendo correctos los títulos originarios, como todos salvo Moirans, y añadirá una restricción que justifica el destino por la necesidad del bien común del orbe en la extracción de metales, consistente en utilizar negros para ese trabajo con la condición de compensar sus esfuerzos. La legitimidad de la institución esclavista permanece incólume mientras las causas de esclavitud sean intachables, pues la segunda transmisión y posteriores gozaban de protección jurídica completa.

Era opinión común entre juristas y teólogos que quien había adquirido de otro poseedor de buena fe podía tener la conciencia segura y no estaba obligado a restituir. Generalmente era lo que sucedía cuando se compraban esclavos etíopes tras repetidas ventas. Cuando surgiera la duda había obligación de investigar en cuanto se ofreciera una oportunidad y solía afirmarse por la mayoría de moralistas una obligación de restitución en proporción a la duda que se mantuviera. Algunos convenían que después de una esclavitud de tantos años, el esclavo fuera liberado, como opinaban Rebello y Avendaño, aunque - dice este último- «sin querer tampoco en esto dar seguridad absoluta» ${ }^{39}$.

En definitiva, todo dependía de la justicia del título originario.

38 Rebello, F., Opus de obligationibus iustitiae, cit., p. 4 B (citando De iustitia Dei, que es obra del jesuita granadino) y p. $72 \mathrm{E}$ (sin referencia a obra alguna).

39 Avendaño, D., Complementos, n. 131 (Avendaño, D., Mineros de Indias y protectores de indios. Thesaurus Indicus, vol. I, Tít. X-XI y complementos, edición de Ángel Muñoz García, Pamplona, Eunsa, 2009, p. 260). 


\subsection{La noticia pública de la injusticia y el deber de restitución}

Sobre la venta dudosa hay un argumento que utilizó Azpilcueta, procedente del Derecho canónico en materia de excomunión y que desborda su potencial interpretativo. Suárez también lo mienta, aunque no indica como ejemplo de interpretación la trata de esclavos, pero podría ser utilizado para fundamentar una solución equilibrada y equitativa en un caso dudoso, porque la doctrina suareciana sobre casos controvertidos en materia moral tiene alcance jurídico general, e incluso en la actualidad repercutiría con utilidad en la comprensión de conceptos indeterminados, sobre la calificación de buena o mala fe, o la comprensión de las causas de exención de responsabilidad por error de hecho o de derecho.

Azpilcueta se refiere a las personas que se venden por necesidad. Esa circunstancia de necesidad extrema no era admitida en el continente europeo como causa de validez de la venta como esclavo, a lo que parece. En cambio, sí era reconocida como válida entre negros o moros, en Brasil y otras regiones asiáticas e incluso en China ${ }^{40}$.

Decía Azpilcueta que había obligación de liberar al hombre comprado que hubiese devenido esclavo sin título, cuando el comprador creía que era libre o debía haberlo creído. El comprador de mala fe no puede alegar ignorancia de la injusticia ${ }^{41}$. Esta no es particularmente distinta de la opinión común, recogida también por Luis de Molina, por ejemplo, de manera que el poseedor pudiera estar tranquilo alegando ignorancia inculpable. La ignorancia soporta la buena fe siempre que el poseedor afirmase que no sabía nada que contradijera la presunción legal ni había podido siquiera llegar a averiguar algo tras hacer las indagaciones oportunas, si es que acaso hubiera surgido la oportunidad de iniciarlas ${ }^{42}$.

La versión latina del Manual de Azpilcueta añade un extenso apartado al número 96 (del capítulo 23), al término del cual se refiere a la Extravagante ad evitanda scandala, que no aparece en las correspondientes versiones

40 Azpilcueta, M., Manual de Confessores y penitentes, cap. 23, n. 95-96; García, F., Tratado utilísimo y muy general de todos los contratos, Parte Primera, cap. 17; Rebello, F., Opus de Obligationibus iustitiae, religionis et caritatis, Prima pars, lib. 1, q. 9, n. 12; ibid., q. 10, sect. 2, n. 24 y n. 34; Molina, L., De iustitia et iure, tr. 2, disp. 33, n. 28-31; ibid., disp. 34, n. 6 y n. 17-19.

41 Azpilcueta, M., Manual de Confessores y penitentes, cap. 23, n. 95 (Salamanca, Andrea de Portonariis, 1556, p. 480).

42 Molina, L., De iustitia et iure, tr. 2, disp. 35, n. 20 (Coloniae Aggripinae, Hermanni Mylii, 1613, col. 193): "si aliquando ex aliquibus circunstantiis contingat, aliquem ex praedictis mercatoribus emisse mancipia cum invincibili ignorantia, quod non essent iusto titulo in servitutem redacta, esto postea ignorantiam depellat, meritoque dubitare incipiat, an iusto titulo servituti fuerint subiecta, teneri quidem facere moralem diligentiam, ut sciat, an iniuste servituti fuerint subiecta, interim tamen dum id non constat, nihil omnino teneri restituere, eo quod in dubio melior sit ipsius conditio qui ab initio bona fide coepit possidere». 
castellanas ${ }^{43}$. Se pregunta si pecan con obligación de restituir los que compran etíopes, indios u otros llevados de sus tierras a otras. Responde que no, siempre y cuando conozcan o crean con probabilidad que se habían vendido a sí mismos voluntariamente, o habían consentido en ser vendidos por otros, o habían sido capturados en guerra justa. Es el planteamiento habitual sobre el poseedor de buena fe, caracterizado si sciunt aut probabiliter credunt.

En cambio, cree con mala fe quien sabe o cree que son esclavos, cuando hay fama pública surgida del relato de quienes son dignos de fe, de que han sido capturados con dolo o con violencia fuera de una guerra justa, o han sido metidos en naves con engaño. Y el doctor Navarro advierte sobre esto último quod aiunt ese frequentissimum, que se dice que estas injusticias son muy frecuentes. Concluye Navarro seguidamente con mención a la constitución Ad evitanda, para mostrar cuándo se evita la fama ${ }^{44}$. Esto es importante, pues de conformidad al derecho canónico la falta de requisitos para considerar la fama o noticia pública, evitaría la obligación de restituir la libertad e indemnizar.

Esa Extravagante pretendía evitar escándalos y tranquilizar las conciencias temerosas de pecar, para lo cual establecía que nadie estaba obligado a evitar la comunicación con otros por razón de una sanción eclesiástica hasta que la sentencia fuese promulgada, denunciada y expresamente declarada por el juez contra una persona en concreto y constara manifiestamente que esa persona en particular había incurrido en sentencia de excomunión, sin que pueda ocultarse o excusarse por algún remedio jurídico ${ }^{45}$.

Esa era la restricción de Martín V al principio de evitar a todo excomulgado, aunque después el Concilio de Basilea propuso mantener la prohibición de comunicar con excomulgados notorios antes de la denuncia, pero no fue

43 Azpilcueta, M., Enchiridion sive manuale confessariorum et poenitentium, cap. 23, n. 95 y 96 (Lugduni, Gullielmum Rovillium, 1584, pp. 629-630). Al final mismo del núm. 96 se refiere a la Extravagante ad evitanda, de la que reproduce una parte algo más adelante, en el cap. 27, n. 35 (p. 804). Es una constitución perpetua aprobada en 1418 por el Papa Martín V en el Concilio de Constanza (1414-1418), para regular el alcance de la sentencia de excomunión y la obligación de los fieles de evitar cualquier contacto con el excomulgado, limitando su alcance con exigencias de publicidad de la sentencia y denominación expresa del condenado.

44 Azpilcueta, M., Enchiridion, cap. 23, n. 96 (op. cit., p. 630).

45 Después de promulgada la Extravagante ad evitanda, solo había que evitar relacionarse con dos clases de excomulgados: a) nominatim denunciati: los que eran pública y especialmente denunciados por su mismo nombre y apellidos, o por su oficio si había uno solamente en el pueblo, de modo que fuera perfectamente declarado y conocido; b) notorii percussores clericorum: la segunda clase de personas vitandas era la del notorio percusor de un clérigo. Pueden verse algunas de las discusiones sobre la interpretación de esta norma canónica en la obra del carmelita VALENTín de LA MADRE DE Dios (Fuero de la conciencia, $7^{\mathrm{a}}$ impresión, Madrid, Francisco Laso, 1707, tratado 5, cap. 2) o, por supuesto, en Francisco SuÁrez a lo largo de su extensa exposición de la pena de excomunión (De censuris, desde la disputa 9 hasta la 24). 
ratificada por la Santa Sede ${ }^{46}$. Azpilcueta no estaba conforme con tantos formalismos jurídicos, pero la realidad social le impone admitir las relaciones sociales entre personas de creencias diferentes que habrían incurrido en reproche canónico, porque la rigidez jurídica para considerar como notoria una excomunión facilitaba la convivencia y permitía mantener contactos con los protestantes. En concreto, el argumento estaba siendo apoyado en las prestigiosas universidades de París, Toulouse y Lovaina. Navarro reconoce que es duro condenar a la gente y justifica que «la necesidad de comunicarse y de negociar hace lícito lo que en otra situación no lo sería» ${ }^{47}$. Por consiguiente, rechazando la vigencia del derecho antiguo, la complejidad de las relaciones humanas en la actualidad y la evidencia de los hechos hacen concluir con la aplicabilidad de esa Extravagante ad evitanda. Esa constitución ha sido probablemente recibida por el uso, con la única limitación de la excomunión manifiesta del que golpee a un clérigo, porque en ésta no hace falta denuncia.

A raíz de esta argumentación comprobamos que según esta constitución extravagante, el conocimiento común de unos hechos sin declaración expresa en forma jurídica no es suficiente para hacer desaparecer la buena fe o la ignorancia invencible. La presunción pende de la noticia pública. Pero lo que se entienda por suficiente para que el conocimiento sea público tiene que atenerse a requisitos jurídicos estrictos. El Derecho está al servicio de la seguridad jurídica y del mantenimiento de la organización social.

Hay una explicación plausible del esquema mental en que se tienen que mover esos pensadores del XVI, que no deja de ser una variación más del dilema permanente de tensión entre la regla y la vida, para insertar el dinamismo social imprescindible para la libertad humana en el marco de instituciones lo suficientemente estables como para hacerlo posible.

La cuestión puede argumentarse de una manera o de otra, pero lo que es relevante es que no existe únicamente una solución correcta en abstracto, al margen de la consideración de las circunstancias peculiares. Francisco Suárez explica el valor de esa Extravagante en sus tratados sobre la excomunión, aunque

46 Ortiz Berenguer, A. M., «La doctrina jurídica sobre la excomunión, desde el siglo XVI al Codex Iuris Canonici», Cuadernos doctorales: derecho canónico, derecho eclesiástico del Estado, N. 13 (1995-1996), pp. 479-528, en especial pp. 492-495.

47 Azpilcueta, M., Enchiridion, cap. 27, n. 35 in fine (op. cit., p. 805): «Nota tertio (...), sed quia durum est damnare gentem, in qua sunt tot viri eruditissimi et academiae celeberrimae praesertim Parisien. Tolosana, et Lovanien.probabiliter dici potest predictam extravagantem esse usu recepta cum sola illa limitatione de excommunicatione manifesta percussionis clerici iuxta tenorem antiquae: vel quod multitudo haereticorum, et necessitas communicandi et negotiandi facit licitum quod alias non esset, iuxta regula quod non est licitum.de regulis iuris». Se está refiriendo a la regla de las Decretales, X. 5, 41, 4 (ed. Friedberg, vol. 2, col. 927): "Propter necessitatem illicitum efficitur licitum. Quod non est licitum lege, necessitas facit licitum. Nam et sabbatum custodiri praeceptum est; Maccabaei tamen sine culpa sua in sabbato pugnabant; sic et hodie, si quis ieiunium fregerit aegrotus, reus voti non habetur». 
no utilice en su argumentación los ejemplos de la esclavitud ${ }^{48}$, pero sí hay otros equivalentes porque afectan a dilemas trágicos y casos de conciencia. El objetivo es persuadir con suficientes razones a la conciencia dudosa para que, ponderando las razones a favor y en contra, pueda tomar una decisión conforme.

\subsection{La vía suareciana de solución y la obligación probable}

Llegando a este punto podemos ver la importancia para el caso concreto de la esclavitud dudosa del planteamiento general acerca de la decisión razonable y la doctrina probabilista ${ }^{49}$.

No interesa tanto la solución concreta que tomaría Suárez sino el curso argumentativo que debería tenerse en consideración para asentar definitivamente una decisión moralmente correcta, aun basada en unas premisas especulativamente inciertas ${ }^{50}$. Suárez es matizado, flexible, pondera con cuidado las distintas posibilidades con que puede verse enfrentado el juicio de la conciencia. Y al final utiliza los criterios tradicionales para obtener el mejor resultado. El principio possidentis, el principio tutior pars y el criterio de la lex dubia están todos ellos al servicio de la solución más razonable en el caso concreto ${ }^{51}$.

48 En efecto, Suárez explica la interpretación de esa Extravagante en la materia de excomunión, entre otros aspectos para entender qué grado de certeza es necesario para que se considere que hay fama pública y por ello surja la obligación de alejarse de los excomulgados. Se ocupa de las condiciones para calificar a la ignorancia como invencible en De censuris, disp. 4 y en sect. 11, n. 11: basta la "publica fama» (según la Extravagante ad evitanda), que la fama sea tal que prudentemente considerada junto con otras circunstancias pueda darse fe al menos probable. Si hubiera duda no surge esa obligación, pues en caso de duda mejor es la condición del poseedor (De censuris, disp. 9, sect. 2, n. 9). Esto merece destacarse, pues la ignorancia invencible siempre excusa la culpa (De censuris, disp. 4, sec. 8, n. 8; Opera omnia, París, Vivès, 1861, tomo 23/1, p. 129).

${ }_{49}$ Algunas monografías recientes señalan la contribución de los jesuitas al casuismo: Turrini, M., La Coscienza e le leggi. Morale e diritto nei testi per la confessione della prima Età moderna, Bologna, Il Mulino, 1991; Maryks, R. A., Saint Cicero and the Jesuits. The Influence of Liberal Arts on the adoption of Moral Probabilism, Aldershot, Ashgate/ Institutum Historicum Societatis Iesu, 2008. La tesis de Robert Maryks muestra la «transición revolucionaria» que hicieron los jesuitas desde el tuciorismo medieval al moderno probabilismo. Vázquez, Suárez y Azor iniciaron el giro probabilista a partir de la adaptación de la fórmula del dominico Bartolomé de Medina (MARYKs, op. cit., cap. 4, pp. 107 ss.) Medina había escrito (Expositio in Summa Theologiae Partem I-II' ${ }^{a}$, q. 19, art. 6): «Mihi videtur quod si est opinio probabilis licitum est eam sequi, licet opposita probabilior sit». Con otros matices, ScHWARTz, D., «Probabilism reconsidered: Deference to experts, types of uncertainty, and Medicines», Journal of the History of Ideas, vol. 75, N. 3 (2014), pp. 373-393.

50 SuÁrez, De bonitate et malitia humanorum actuum, disp. 12, sect. 1, n. 6. Suárez construye su argumentación sobre la distinción entre juicios de la conciencia especulativos y juicios prácticos; además incorpora la diferencia entre dudas de hecho y de derecho. Al respecto, una brevísima síntesis en MARYKS, R., op. cit., pp. 123-125.

51 SuÁrez, De bonitate et malitia humanorum actuum, disp. 12, sect. 5, n. 6 (Opera omnia, París, Vivès, 1856, t. 4, p. 448): «iudicium practicum conscientia, ut supra dixi, prudentiale 
Entre las distintas corrientes probabilistas Suárez jamás está en los extremos, ni laxismo ni rigorismo. No milita en una rígida escuela que ahorme férreamente la necesaria adaptación a las circunstancias imprevistas. Parece, por ello, optar Suárez por un probabilismo matizado, que acoge la mejor solución para evitar el daño ${ }^{52}$. Es muy flexible y matizado, alejado de la rigidez formal legalistavoluntarista que le asignan sus oponentes ${ }^{53}$. No es fácil calificar al Eximio, ni conviene etiquetarlo en una corriente: probabilismo puro, probabiliorismo, tuciorismo o rigorismo.

Cuando conviene argumenta con un criterio o con otro. Creo poder afirmar que el extenso desarrollo que hace el Eximio de esta cuestión sobre la duda probable es una anticipación de los procedimientos actuales de razonamiento práctico en el ámbito jurídico, que han venido imponiéndose en paralelo con el desarrollo del constitucionalismo en el actual modelo de Estado constitucional ${ }^{54}$.

En ocasiones argumenta hacia la preferencia por favorecer la libertad, pero cuando esta solución ponga en cuestión la autoridad del legislador y la seguridad jurídica optará claramente por defender la obligatoriedad de la ley. Hay una presunción de justicia de la acción del soberano y de validez de sus leyes ${ }^{55}$, e incluso Suárez afirmará la presunción de validez de los impuestos en una época en que se cuestionaba seriamente la intromisión del monarca en la propiedad por los excesivos y novedosos tributos, haciendo más antipática todavía la defensa de una recaudación estable, contradiciendo la opinión vulgar de que uno podía dejar de cumplir la ley o de pagar los impuestos cuando surgiera una duda probable de su injusticia ${ }^{56}$.

Dice Rudolf Schüssler que Suárez se inclina por sustituir la aplicación del principio más rígido en aras de otro principio más favorecedor de la libertad ${ }^{57}$.

est, sed proprium prudentiae principium est in singulis actionibus id esse agendum, quod minus habet incommodi, atque hoc modo his etiam verum habet illud principium: In dubiis tutior pars est eligenda. Applicare vero hanc regulam ad singulos actus munus est potius prudentiae quam scientiae, pendet enim ex singularibus contingentibus, quae non cadunt sub scientiam».

52 Abellán, P. M., «Posición de Suárez ante el conflicto entre la libertad y la obligación probable», en Actas del Congreso Internacional de Filosofía. Barcelona, 4-10 de Octubre de 1948, vol. III, Madrid, Instituto «Luis Vives de Filosofía», 1949, pp. 56 y 58.

53 Stone, M. W. F., «The scope and limits of moral deliberation. Ratio recta, natural law, and conscience in Francisco Suárez», en Nauta, L. y Pätzold, D. (eds.), Imagination in the Later Middle Ages and Early Modern Times, Leuven, Peeters, 2004, p. 56.

54 En este sentido, Pérez Luño, A.-E., «Los clásicos españoles del Derecho natural y la rehabilitación de la Razón práctica», Doxa, 12 (1992), pp. 321-322.

55 GARZÓN VALDÉs, E., «Las palabras de la ley y su interpretación: Algunas tesis de Francisco Suárez», en Id., Derecho, ética y política, Madrid, Centro de Estudios Constitucionales, 1993, pp. 117-129.

56 Suárez, F., De legibus, lib. 5, cap. 18. Cf. Amezúa Amezúa, L. C., «La potestad tributaria en Francisco Suárez», Anales de la Cátedra Francisco Suárez, vol. 51 (2017), pp. 209-231.

57 Schüssler, R., "On the Anatomy of Probabilism», en Kraye, J. and SaArinen, R. (eds.), Moral Philosophy on the threshold of modernity, Dordrecht, Springer, 2005, pp. 91-114. En este trabajo sitúa a Suárez con Tomás Sánchez entre los promotores de un probabilismo 
Ahora bien, podemos decir con Suárez que eso es así a veces, y que otras veces no es así. Porque hay ocasiones en que debe prevalecer la obligación legal frente a la libertad. Hay otras en que prefiere al poseedor del derecho frente al que duda: esto lo aplica en el ámbito bélico, pues el poseedor actual del derecho que tenga dudas prevalece ante el que pretende lo mismo y dude igualmente ${ }^{58}$. Aplica también el principio possidentis cuando se duda de la validez del voto emitido: en esta ocasión el principio juega en beneficio de la libertad del votante, prefiriendo al poseedor actual de la libertad, frente a la solución más segura que impondría la validez del voto ${ }^{59}$. Lo mismo respecto a dudas sobre la exigibilidad del débito conyugal cuando se duda de la validez del matrimonio, permitiendo un plazo razonable, incluso de algunos años, para comprobar si realmente el matrimonio ha sido válidamente consumado ${ }^{60}$. Pero el principio possidentis, incluso entendido como principio que mantiene al poseedor actual del derecho en su poder, puede beneficiar al poseedor del derecho de propiedad, o favorecer al poseedor del derecho de libertad.

En el caso del esclavo, la aplicación del principio possidentis podría abocarnos a defender el derecho actual del dueño. A esa misma solución podría conducirnos también el probabiliorismo, si resultara más probable que el esclavo haya sido justamente cautivado que lo contrario; o incluso aunque sean igual de probables una solución que otra. Si aplicáramos el principio tutior pars, optar por la solución más segura, ello supondría mantener la validez de la transacción, porque ha sido realizada cumpliendo todas las formalidades legales, superando los trámites burocráticos, visados administrativos, tasas e impuestos, que hacen gozar de presunción de validez lo que aprueban los funcionarios del gobierno.

Schüssler contrapone la opción possidentis a la opción lex dubia, como si la primera no favoreciera la libertad. Esto no es así siempre. Es más, una regla general que se aplicara ciegamente, al margen de las circunstancias, producirá consecuencias de rigidez e injusticia mayores que la ponderación, por mucha

orientado a la libertad personal, un «liberty-centred probabilism»; frente al «informationcentred» probabilismo de Bartolomé de Medina, más centrado en la mitigación de los costes de información en la toma de decisiones. En el siglo XVI el principio "possidentis» (en caso de duda mejor es la condición del poseedor actual) fue usado con frecuencia para restringir la libertad de los individuos, aunque no siempre. Los críticos restringieron ese principio al ámbito de los derechos de propiedad mientras que en el campo moral preferían utilizar el principio «lex dubia» (una ley u obligación dudosa no obliga). Francisco Suárez hizo de este último la piedra angular - dice Rudolf Schüssler- de su probabilismo y con ello anticipa el liberalismo moderno (ibid, pp. 100 y 103-105). Algunas aclaraciones más: Id., "Moral self-ownership and ius possessionis in scholastics», en MäKInEn, V. y Korkman, P. (eds.), Transformations in medieval and early-modern rights discourse, Dordrecht, Springer, 2006, pp. 149 ss.

58 SuÁREZ, De charitate, disp. 13, sect. 6, n. 2-3.

59 SuÁrez, De bonitate et malitia humanorum actuum, disp. 12, sect. 5, n. 5; De religione, tract. 6, lib. 4, cap. 5 .

60 SuÁreZ, De bonitate et malitia humanorum actuum, disp. 12, sect. 5, n. 8 . 
imprevisibilidad o incremento de la inseguridad que dificulte anticipar la solución de manera abstracta ${ }^{61}$. En esto Suárez es muy atractivo para los interesados en mostrar los recovecos del razonamiento práctico aplicado a situaciones difíciles.

Sin embargo, no puedo concluir con una solución tajante. Si acaso, con una solución moralmente cierta, aunque estuviera basada en premisas teóricamente inciertas - como sostiene Suárez-, siempre que estas hayan sido construidas con un error insalvable (certeza moral), tras mostrar diligencia en recabar los datos para construir las premisas y obrar de buena $\mathrm{fe}^{62}$. En cada caso concreto se verá la solución.

El teólogo granadino podría argumentar en un sentido o en otro, porque el fin que pretende es consolidar un orden justo de convivencia, respecto del cual no se oponen derechos individuales sino que se enmarcan en él ${ }^{63}$. La perspectiva con la que reflexiona Suárez es menos la del pensador que busca configurar la libertad del individuo que la del que inserta a las personas en el marco de una pluralidad de comunidades de vida solapadas, cada una de las cuales imprescindible para que obren en ellas los miembros.

\section{ConcLusión}

Para concluir respecto de los esclavos negros: Suárez no es abolicionista ni tampoco, a lo que parece, facilita incorporarle al grupo de los más reticentes. Hemos recogido las opiniones de Las Casas, Soto, Mercado, Albornoz y también otras posteriores, las de Molina, Rebello, Avendaño, como representativas de los más reticentes (Moirans es una excepción por su radicalismo). Son pioneros en las críticas a la trata negrera, aunque no se opusieran a la institución de la esclavitud. Todavía siglos después los ilustrados serán en exceso ambiguos y en las cátedras de jurisprudencia a comienzos del XIX expondrán tratadistas del derecho civil la justa servidumbre de los negros esclavos, en virtud del contrato de compraventa y de la buena fe con que son recibidos, sin deslegitimar la adquisición originaria por los títulos tradicionales del derecho de gentes, "O por otros modos aprobados por sus respectivos soberanos ${ }^{64}$, a la manera que había formulado Solórzano Pereira, sólo que dos siglos antes, como si el tiempo y las ideas fueran coriáceas a la moral y a la justicia, nada más que permeables a los requerimientos del sistema económico.

Comparados con estos personajes decimonónicos, nuestros teólogos críticos

61 SuÁrez, De bonitate et malitia humanorum actuum, disp. 12, sect. 5, n. 2-9.

62 Sú́rez, De bonitate et malitia humanorum actuum, disp. 12, sect. 3, n. 3; sect. 5, n. 3; sect. 6, n. 9 .

63 BRUST, S. J., «Retrieving a catholic tradition of subjective natural rights from the late scholastic Francisco Suárez, S.J.», Ave Maria Law Review, vol. 10 (2012), pp. 342-363.

64 Álvarez, J. M., Instituciones de derecho real de España, Tomo 1, Madrid, Imprenta de Repullés, 1829, p. 38. 
tuvieron más difícil superar el paradigma dominante que había convertido a la esclavitud en una institución esencial para el desarrollo económico de su época. Todos la veían bien, la gente que podía tenía esclavos en propiedad, de cualquier estamento que fuese, las órdenes religiosas incluidas. De hecho, los jesuitas tuvieron en sus haciendas trabajadores negros a quienes trataron suavemente y favoreciéndoles, sin embargo el rendimiento de la producción fue aplicado sobre todo al esfuerzo evangelizador de los indios ${ }^{65}$.

Apreciamos su esfuerzo teórico, la manifestación clara de la realidad de la esclavitud sin camuflaje, lo cual era inconveniente para sus países, para los gobernantes y para quienes sacaron beneficios. Hizo falta divulgar estas ideas durante centurias para que calase en la conciencia colectiva la noble idea de la fraternidad, para comprender la verdad de lo que estaba sucediendo a la vista de todos, que no era sino el sacrificio de hombres de color con excusas inaceptables y que perpetuaba la ignominiosa esclavitud, destruyendo pueblos y personas, exterminando a los negros en beneficio de unos cuantos aprovechados. Y con ello, degradando la humanidad de los explotadores que poco de cristianos y de humanidad podían acreditar.

La "cláusula suareciana», entendida en su contexto, puede acaso interpretarse como reparo especial porque propone una limitación práctica que en algo, por poco que fuera, mejoraría la situación de los esclavos. No anticipa reproches serios a la esclavitud ni a la trata, de manera que tampoco contribuye a la anticipación de los derechos humanos. Esa fórmula aislada no lo apoya, aunque en otras ocasiones Suárez había defendido el respeto a minorías acosadas, a los moriscos, a los indios, a presos fugados. Su talante general no fue el de un pensador reaccionario. Sin embargo, considero que su preocupación principal se orientó a mantener las instituciones, de ahí que siempre pretendiera conseguir un equilibrio entre lo que hoy denominaríamos derechos individuales y el mantenimiento del orden social. Importaba mantener las instituciones que hacían posible la vida en relación y la convivencia en las diversas comunidades territoriales o personales donde se desenvuelve la vida humana.

Universidad de Valladolid. (España)

Luis-Carlos Amezúa Amezúa

Facultad de Derecho

amezua@der.uva.es

[Artículo aprobado para publicación en enero de 2018]

65 Vid. Medina, F. de Borja, «El esclavo: ¿bien mueble o persona? Algunas observaciones sobre la evangelización del negro en las haciendas jesuitas», en NEGRo, S. y MARZAL, M. M. (compiladores), Esclavitud, economía y evangelización. Las Haciendas jesuitas en la América virreinal, Lima, Pontificia Universidad Católica del Perú, 2005, pp. 83-122; TARdieu, J. P., "Semiología del "silencio" de los jesuitas ante la esclavitud de los Negros en Hispanoamérica», en Gonzales, D. A. et al. (Eds.), Escrituras silenciadas. Poder y silencio en la península ibérica y América, Alcalá de Henares, Universidad de Alcalá, 2015, pp. 17-27. 